\title{
NORTH AMERICAN WIDOW SPIDERS OF THE LATRODECTUS CURACAVIENSIS GROUP (ARANEAE: THERIDIIDAE)
}

\author{
By John D. McCrone ${ }^{1}$ and Herbert W. Levi ${ }^{2}$
}

Our taxonomic knowledge on widow spiders was summarized in a previous study of Latrodectus (Levi, I959). However, at the time it was known that there were several areas of difficulty: the Near East, where several species with similar genitalia occur; and northern Argentina, where one or two additional species are found (Abalos, 1962). Field and laboratory work in Curaçao, Lesser Antilles, and in Florida, as well as additional specimens, have provided many more data on the species called L. curacaviensis in the previous paper.

We wish to thank Drs. B. de Jong of Curaçao and Dr. I. Kristensen of the Caribbean Marine Biological Institute, Curaçao, for their hospitality and help in the field work on the island. We are also grateful to Dr. P. Wagenaar Hummelink, Dr. L. van der Hammen and Mr. P. J. van Helsdingen of the Natural History Museum, Leiden, for specimens collected in the Netherlands Antilles. Dr. A. R. Brady photographed the Abbot manuscript with the help of the staff of the British Museum (Natural History), Mr. J. Beatty provided specimens from Florida, and Mr. P. Dell gave technical assistance.

This investigation was supported in part by Public Health Service Research Grant AI-OI944 from the National Institute of Allergy and Infectious Diseases and Public Health Service Research Grant GM I 206-OI from the National Institute of General Medical Sciences.

\section{Descriptions and Nomenclature}

The specimens considered to be $L$. curacaviensis in the previous paper belong to several species. Only females from the type locality of L. curacaviensis were examined; males are unknown from the type locality, and the species seems to have disappeared from the island of Curaçao. The specimens examined were collected by Hasselt over one-hundred years ago (Hasselt, i860, i 887). The specimens considered to be curacaviensis from Argentina (Levi, 1959) also appear to belong to two or more species. The oldest name for the additional

${ }^{1}$ Florida Presbyterian College, St. Petersburg, Florida.

${ }^{2}$ Museum of Comparative Zoology, Harvard University.

Manuscript received by the editor February 25, 1964. 
species is probably one given by Nicolet ( 1849 ), who named several Latrodcctus from Chile.

\section{Latrodectus curacaviensis (Müller)}

Figures I, I6, I7

Aranea curacaviensis Müller, 1776, p. 242. Female type from Curaçao. Netherland Antilles, lost.

Latrodectus curacariensis, - Levi, 1959, p. 38 (in part).

Description of female specimen from Curaçao: Carapace light yellow-brown, slightly darker in thoracic depression and around margin. Sternum darker yellow-brown with a narrow median longitudinal lighter mark. Legs light yellow-brown; patellae, distal ends of femora, and tibiae slightly darker. Abdomen black with white marks (Fig. I6, I7) that are lighter around the edge than centrally, and presumably were red in the live animal. Carapace comparatively long. Total length $6.5 \mathrm{~mm}$. Carapace $2.6 \mathrm{~mm}$ long, $1.4 \mathrm{~mm}$ wide. First femur $3.8 \mathrm{~mm}$. Patella and tibia $4.2 \mathrm{~mm}$, metatarsus $3.8 \mathrm{~mm}$, tarsus r.3 mm. Second patella and tibia $2.7 \mathrm{~mm}$, third $\mathrm{I} .9 \mathrm{~mm}$, fourth 4.0 $\mathrm{mm}$.

\section{Latrodectus variolus Walckenaer (Northern Widow)}

Figures 3, 8-1 3, 27

Latrodectus variolus Walckenaer, 1837, p. 648. Female lectotype here designated: Abbot manuscript figure 391, manuscript in the British Museum (Natural History) library.

Latrodectus curacaviensis, - Levi, 1959, p. 38 (in part; not L. curacaviensis Muller)

Note: Abbot manuscript figure 39I was chosen lectotype because Abbot described two ventral transverse bars on the specimen, a characteristic of the species (Fig. 27) that distinguishes it from L. mactans, which has an hour glass (Fig. 26). It presumably came from the Beaver Dam Creek area, Screven County, near where Abbot lived in the I790's, in a part that used to be Burke County.

The comments to Abbot's figures are (in original spelling):

"I9I Aranea Taken 28th May in the Oak Woods. very rare []

I94 Aranea 'Taken I5th May on Oak, in Oak Woods. Rare [juv. o]

195 Aranea Taken 23 Feb. under a Stone. It has a large angulated red spot beneath the Abdomen. It makes an irregular Web, under old Logs and Rails, not very common. 
The bite of the Species of spider is accounted very poisonous [o]

39I Aranea Taken 5th April on a small Pine Bush in the Oak Woods of Burke County. Beneath the abdomen is black with two transverse red Bars, Rare [juv. $\sigma^{\top}$ ]

396 Aranea Taken 30th June in a Dirt daubers Nest. very Rare [juv. $\left.0^{\prime}\right] "$

Walckenaer's names for Abbot's figures and their probable disposition are:

Fig. 191 Latrodectus formidabilis Walckenaer, I838, p. $647[=L$. variolus]; Fig. I94 Latrodectus variolus Walckenaer, I838, p. 648; Fig. 195 Latrodectus perfidus Walckenaer, 1838, p. 647 [= L. mactans]; Fig. 391 Latrodectus variolus Walckenaer, I838, p. 648; Fig. 396 Latrodectus variolus Walckenaer, I838, p. 648.

Description of female from Torreya State Park, Liberty County, Florida: Carapace brownish black. Sternum, legs, abdomen, black. Dorsum often with a median longitudinal row of red spots. Venter with two transverse red bars (Fig. 27). Total length I I mm. Carapace $4.2 \mathrm{~mm}$ long, $3.8 \mathrm{~mm}$ wide. First femur, $8.0 \mathrm{~mm}$; patella and tibia, $9.8 \mathrm{~mm}$; metatarsus, $8.3 \mathrm{~mm}$; tarsus, $2.5 \mathrm{~mm}$. Second patella and tibia, $5.0 \mathrm{~mm}$; third, $4.2 \mathrm{~mm}$; fourth, $7.3 \mathrm{~mm}$.

Male from Torreya State Park: Carapace brown. Sternum dark brown. Legs: coxae dark brown; proximal portion of first femora, brown; patellae brown; other parts orange, except brown at distal ends of tibiae. Abdomen black, dorsum variable with two to three red spots in a median longitudinal line; sometimes orange lines going down sides from spots, and a line above spinnerets. Venter with two red transverse bars. Total length $6.7 \mathrm{~mm}$. Carapace $2.7 \mathrm{~mm}$ long, 2.I mm wide. First femur, $6.5 \mathrm{~mm}$; patella and tibia, $7.6 \mathrm{~mm}$; metatarsus, $7.3 \mathrm{~mm}$; tarsus, $2.1 \mathrm{~mm}$. Second patella and tibia, 4.2 $\mathrm{mm}$; third, $2.7 \mathrm{~mm}$; fourth, $5.9 \mathrm{~mm}$.

Female from Dover, Massachusetts: Color as in Florida female. Abdominal dorsum with a median row of three to four spots above spinnerets. Lines on sides of spots. Venter with two transverse marks that, like the spots, were probably red in the live animal. Total length $9.2 \mathrm{~mm}$. Carapace $3.2 \mathrm{~mm}$ long, $3.4 \mathrm{~mm}$ wide. First femur, $5.9 \mathrm{~mm}$; patella and tibia, $6.0 \mathrm{~mm}$; metatarsus, $5.5 \mathrm{~mm}$; tarsus, $\mathrm{I} .8 \mathrm{~mm}$. Second patella and tibia, $3.9 \mathrm{~mm}$; third, $2.6 \mathrm{~mm}$; fourth, $5.2 \mathrm{~mm}$.

Male from Vermont: Carapace, sternum and legs, brown. Abdomen black with four dorsal spots in a longitudinal median row and some spots on sides. Venter with two transverse marks probably red in 
live animal. Total length $6.5 \mathrm{~mm}$. Carapace $2.9 \mathrm{~mm}$ long, $2.6 \mathrm{~mm}$ wide. First femur, $6.7 \mathrm{~mm}$; patella and tibia, $6.9 \mathrm{~mm}$; metatarsus, $7.0 \mathrm{~mm}$; tarsus, $2.0 \mathrm{~mm}$. Second patella and tibia, $4.2 \mathrm{~mm}$; third, $3.0 \mathrm{~mm}$; fourth, $5.6 \mathrm{~mm}$.

Distribution. Southern Canada, United States, northern Florida, Texas to central California (records of $L$. curacaviensis, - Levi, I958 except those of central and southern Florida).

\section{Latrodectus bishopi Kaston (Red Widow)}

Figures 2, 4-7, 2 I-22

Latrodectus mactans var. bishopi Kaston, 1938, p. 60. Male holotype from Lake Worth, Florida, in the American Museum of Natural History, examined.

Latrodectus curacaviensis, - Levi, 1959, p. 38 (in part, central and southern Florida records, not $L$. curacaviensis Müller).

Description. Specimens from I $8 \mathrm{~km}$ ( I I mi.) south of Lake Placid, Highlands Co., Florida: Female. Carapace orange with dark rings around eyes. Sternum, legs orange. Abdomen black without any marks, or with median red dorsal spots, or red spots surrounded by a yellow border. Total length $8.5 \mathrm{~mm}$. Carapace $3.4 \mathrm{~mm}$ long, 2.5 $\mathrm{mm}$ wide. First femur, $6.9 \mathrm{~mm}$; patella and tibia, $6.9 \mathrm{~mm}$; metatarsus, $6.8 \mathrm{~mm}$; tarsus, $2.3 \mathrm{~mm}$. Second patella and tibia, $4.2 \mathrm{~mm}$; third, $2.9 \mathrm{~mm}$; fourth, $5.5 \mathrm{~mm}$.

Male: Carapace, sternum, legs, orange. Abdomen black, with a variable number of spots. Usually two to three median dorsal red spots in a longitudinal line and some light marks on the side. Line above spinnerets absent and venter black or with spots. Total length $4.2 \mathrm{~mm}$. Carapace $2.1 \mathrm{~mm}$ long, $\mathrm{I} .7 \mathrm{~mm}$ wide. First femur, $5.5 \mathrm{~mm}$; patella and tibia, $5.9 \mathrm{~mm}$; metatarsus, $5.9 \mathrm{~mm}$; tarsus, $1.4 \mathrm{~mm}$. Second patella and tibia, $3.5 \mathrm{~mm}$; third, $2.2 \mathrm{~mm}$; fourth, $4.4 \mathrm{~mm}$.

Distribution. Central and southern Florida, in sand-pine scrub. (Central and southern Florida records of L. curacaviensis, - Levi, 1959).

\section{Diagnosis}

Latrodectus curacaviensis, L. variolus and L. bishopi differ from L. mactans by their genitalic structure: L. mactans has one more loop in the embolus of the palpus and one more loop in the connecting ducts of the internal female genitalia. All specimens of $L$. mactans from the eastern and southern United States have an hour-glass mark on the venter (Fig. 26) with the exception of some from southern Texas and Mexico. Latrodectus variolus usually has two transverse 

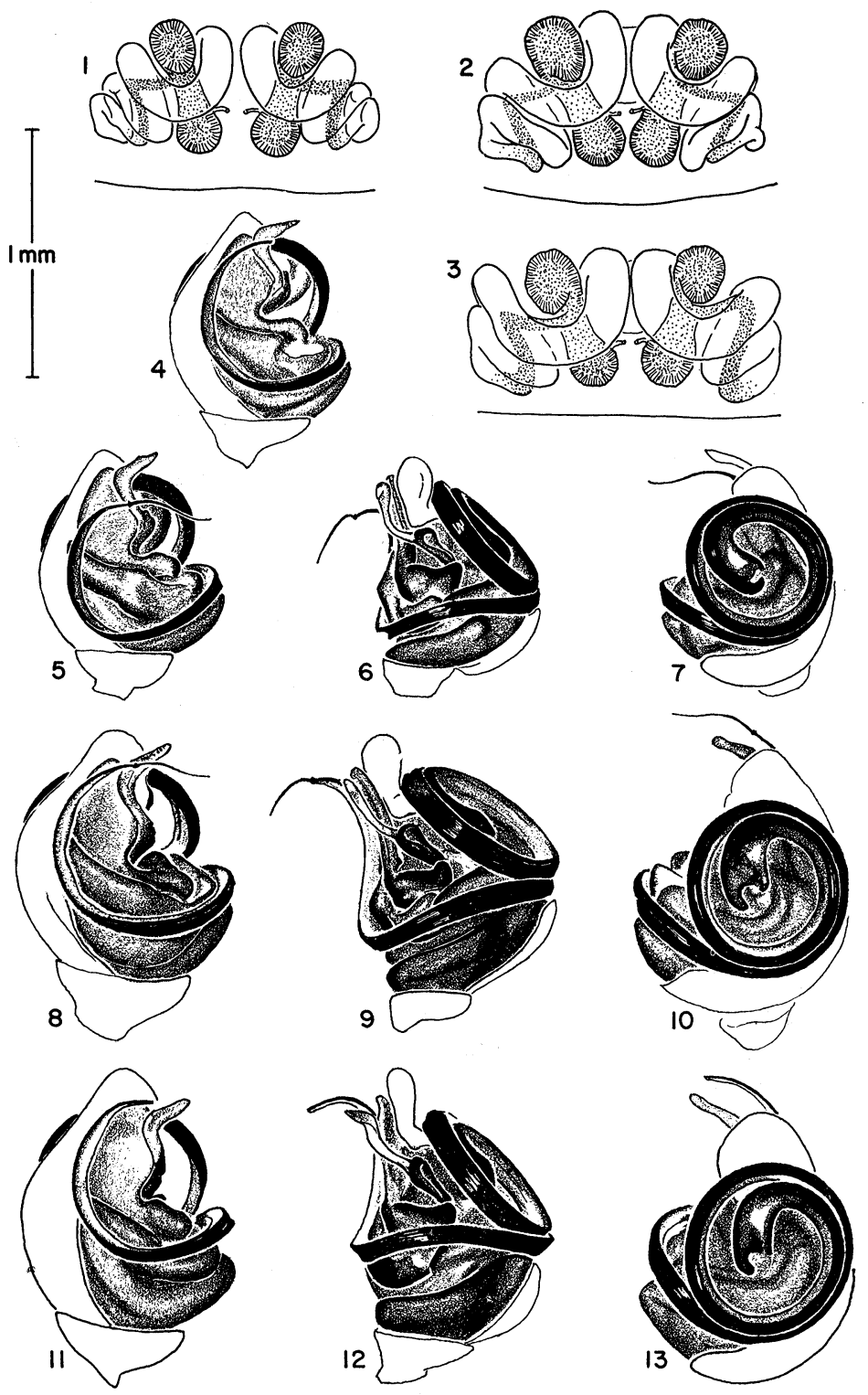

McCrone and I.evi - Latrodectus 
red bars on the venter (Fig. 27); the anterior bar may be triangular. Of the specimens examined only one male from South Carolina was found to have an hour-glass. Kaston (1948, figs. IOI-IO4) noticed the reduction of the hour-glass in specimens which he thought were northern specimens of $L$. mactans. Latrodectus bishopi also lacks a complete hour-glass and may have two ventral spots, one or none (Figs. 2 I-22).

Males of $L$. bishopi and $L$. variolus are much larger than those of L. mactans; male from Torreya State Park had the carapace $2.7 \mathrm{~mm}$ long, first patella and tibia $7.6 \mathrm{~mm}$; a male from Vermont, 2.9; 6.9. Males of L. mactans, though smaller, are variable. Comparative measurements from Brewster Co., Texas, I.4; 3.7; from Silverhill, Alabama, I.7 ; 4.3 ; from Savannah, Georgia, 2.I ; 5.6 ; and from Punta Gorda, Florida, I.7; 4.3 .

Latrodectus curacaviensis, L. variolus and Latrodectus bishopi are allopatric in distribution and can be separated by the coloration of the carapace, sternum and legs: orange-red in $L$. bishopi; black in $L$. variolus, light brown in L. curacaviensis from Curaçao. The genitalia of the three species are surprisingly similar (Figure I-I3); however, among Florida specimens there seem to be slight differences in the shape of the hard sclerotized parts of the palpus. These differences are not seen between $L$. bishopi and New England specimens of $L$. variolus. Latrodectus curacaviensis seems to be smaller and more colorful (Figs. I6, I7) than the other two. It also has a comparatively long carapace. A similar pair of Latrodectus species is L. mactans tredecimguttatus (Rossi) and L. pallidus O. P. Cambridge in the Near East, differing in color and texture of the abdomen, but not in the structure of genitalia.

\section{Coloration}

It is well known that juvenile widows are brighter colored, with streaks and marks, than the adults. It was completely overlooked in

Explanation of Plate 2

Figs. 1-3. Cleared dorsal view of epigyna. 1. Latrodectus curacaviensis (Müller) from Curaçao. 2. L. bishopi Kaston. 3. L. variolus Walckenaer from Torreya State Park, northwestern Florida.

Figs. 4-7. Latrodectus bishopi Kaston, left male palpus. 4. Mated individual. 5-7. Virgin individual. 4, 5. Mesal view. 6. Ventral view. 7. Ectal view.

Figs. 8-10. Latrodectus variolus Walckenaer, male palpus, virgin individual from Torreya State Park, northwestern Florida. 8. Mesal view. 9. Ventral view. 10. Ectal view.

Figs. 11-13. Latrodectus variolus Walckenaer, male palpus, mated individual from Vermont. 11. Mesal view. 12. Ventral view. 13. Ectal view. All figures are drawn at the same magnification. 
the previous paper that there is a striking correlation between total length of the spider and the coloration of different forms, the smaller ones being brighter colored, the largest ones dark. As shown below there is some variation among individuals in the number of molts undergone and it is possible that the brighter colored and smaller $L$. curacaviensis undergoes fewer molts than $L$. bishopi and $L$. variolus, and that the brightly colored populations of $L$. mactans in some parts of the world are made up of individuals that undergo fewer molts before maturity. Differences in the number of molts (4-9) of males with accompanying large differences in color and size in a laboratory culture of the araneid Nephila madagascariensis Vinson was reported by Gerhardt ( I 933 ).

\section{Natural History}

A trip was made to Curaçao in December, 1962, during the wet season. Despite a thorough search of the island, no L. curacaviensis were found. We had previously been advised by Drs. de Jong, a student of spiders and long time resident, that he had been unable to find the species, described in 1776 by Müller, and collected by Hasselt in 1860 . Two factors may have led to its disappearance. First, the habitat probably has become less favorable. Thirty thousand goats roam the island and they appear to have placed a strong selection pressure on the vegetation, favoring plants with long spines and those that are poisonous. Shulov (1940) has reported that an area heavily infested with $L$. pallidus was almost freed of them by the grazing of cows and goats. Furthermore, on this densely populated island any woody plants are cut for fuel. Both of these ecological factors may have contributed to the increased dryness of the island. One Latrodectus collecting site of Hasselt was visited and was found to be moister than the island generally. Second, the introduced L. geometricus may have replaced $L$. curacaviensis, even though L. geometricus appears to be most abundant near Willemstad and human habitations.

Although they are very similar morphologically, L. bishopi and the Florida populations of $L$. mactans and $L$. variolus can easily be differentiated on the basis of their color, ecology and behavior.

Latrodectus bishopi shows a very distinct habitat preference. It is completely restricted to inland, dune-like areas that support a plant association called sand-pine scrub (Fig. 23). The vegetation is xeromorphic and is dominated by the sand pine, Pinus clausa. Beneath the pines there is a dense growth of evergreen shrubs but little or no herbaceous ground cover. For a more complete description of the association see Laessle ( 1958). 

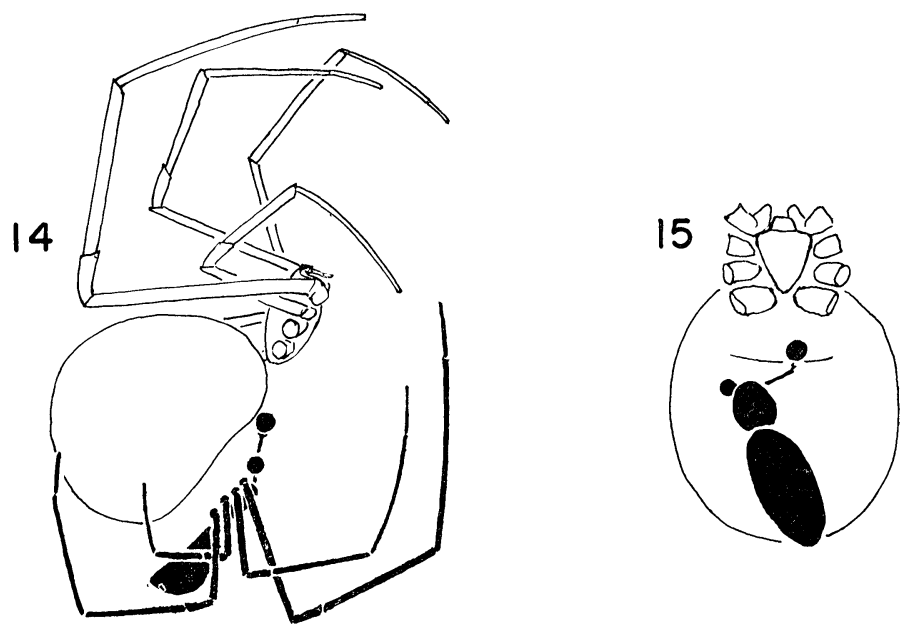

Figs. 14, 15. Latrodectus bishopi Kaston, mating position. Male black, female in outline. Web supporting the spiders not shown.

Within the scrub, L. bishopi almost always makes its webs $30 \mathrm{~cm}$ or higher off the ground in the palmetto bushes, Serenoa repens and Sabal etonia (Fig. 24). The spider makes its web retreat by taking a frond of the palmetto and rolling it into a cone. The interior of the cone is lined with silk and the egg sacs are hung from the sides of the cone (Fig. 25). The egg sacs are light gray to white in color and have a fairlv soft texture unlike those of $L$. mactans and $L$. variolus, which are brown and papery (Figs. I 8-20). Often a mature male is found in the cone-shaped retreat with the female. There is little difference in the sizes of the sexes and a small silk partition usually separates them. The outer threads of the web spread from frond to frond of the palmettos and form a sheet-like pattern. The web is completely free of insect remains in contrast to those of $L$. mactans and $L$. variolus, which are heavily festooned with them. The reason for this may be that $L$. bishopi feeds only on very softbodied insects or ejects the remains from the web. The developing spiderlings remain in the parental web until they are half-grown whether the mother is still alive or not.

The courtship and copulatory behavior of $L$. bishopi have been observed in the laboratory in Cambridge. A male was placed with an adult female on 22 March I963 at 7:00 A. M. Ten minutes later their legs were I cm apart and the male's abdomen jerked three times. 


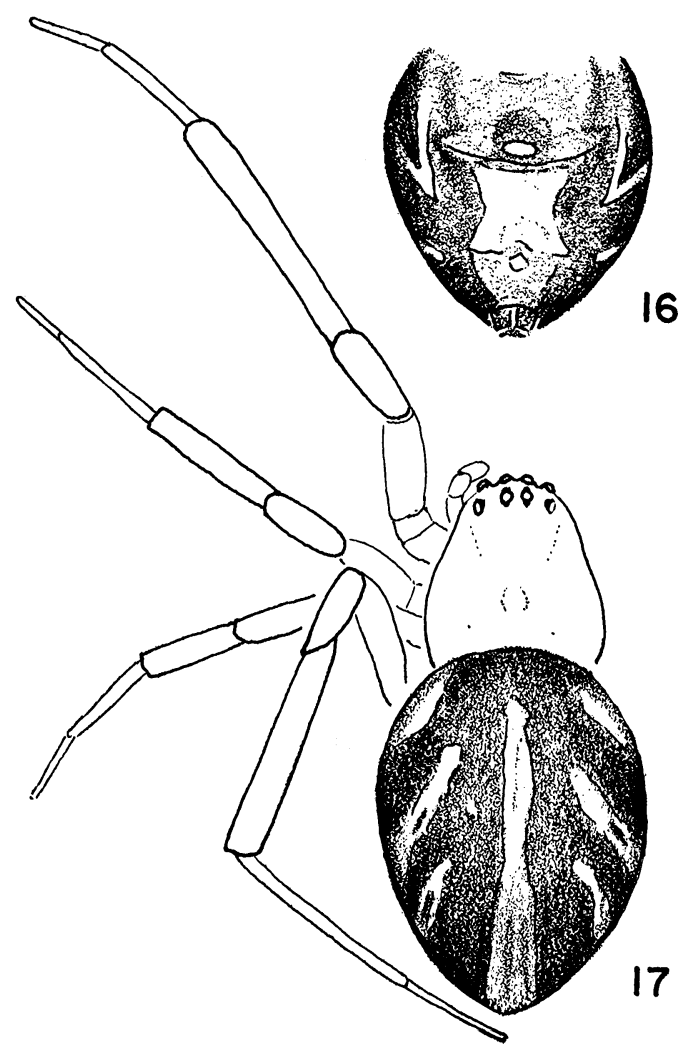

Figs. 16, 17. Latrodectus curacaviensis (Müller), female. 16. Ventral view of abdomen. 17. Dorsal view.

At $7: 29$, after climbing around, the male moved behind the female jerking the web, and using his long forelegs touched the first legs of the female with his and then climbed on the dorsum of the female's abdomen, facing in the opposite direction. The female kept completely still even though the male was climbing around her. The male vibrated his abdomen occasionally and sat behind the female touching her first leg with his. By 7:42 the male had moved below the female. The female was completely inactive while the male climbed around and boxed her epigynum. At 7:44 the male came to rest below the female's abdomen, facing in the same direction, and seemed to insert one or the other palpus in the epigynum while pulling the female's abdomen up slightly with his fourth leg. His abdomen continued to vibrate and he kept boxing the epigynum without quite touching it. At 7:50 the 
right palpus was inserted and withdrawn after four minutes. The male then rested behind the female, vibrating his abdomen. Soon he moved anteriorly and shook the web. At $8: 02$ he inserted the left palpus. Both animals were quiet, then the male moved its legs and shook both the web and the female. After II minutes the left palpus was withdrawn; it was pulled back about $2 \mathrm{~mm}$ while the embolus stretched like a pulled-out watch spring and then suddenly snapped back (apparently the distal portion broke off, see Abalos, et. al. I963). The male again moved behind the female, boxed her epigynum, vibrated his abdomen and jerked the female. At $8: 3 \mathrm{I}$ he seemed to introduce the right palpus again, then moved back, boxed her abdomen and palpated her sternum with his palpus. At 8:37 he inserted the right palpus again and pulled back slightly (Figs. I4, I5). After insertion all was quiet except that the male occasionally moved his legs and jerked the female. At 9:07, 30 minutes later, the palpus was withdrawn 3-4 $\mathrm{mm}$ with the embolus again stretching. Suddenly it snapped back and the male moved behind the female. At 9:1 3 he began boxing the epigynum and vibrating his abdomen. Alternately with boxing the epigynum he cleaned his palpi against each other and the chelicerae. After this the male moved $2 \mathrm{~cm}$ in front of the female. At 9:22 the glass was accidentally jarred and the male and female moved off in opposite directions.

Latrodectus variolus is found in mesic and xeric deciduous forests and is particularly abundant in Torreya State Park in northwest Florida. There the adults make their webs in trees, 3 to 20 feet off the ground (Fig. 28). They build dome-shaped retreats in the leaves at the ends of branches and the outer threads of the web radiate out from the retreat to the surrounding branches. The females and any egg sacs are usually found in the retreat. The webs contain many insect remains, primarily those of large flying insects such as cicadas.

During March and April large numbers of immature L. variolus are found at the bases of stumps in mixed forest litter. In the summer, however, the adults are found in the trees. The migration up into the branches has not been observed.

In Wisconsin, L. variolus has been collected from Baxter's Hollow in Sauk County and Wildcat Mountain in Vernon County. Both are natural undisturbed forest areas. On Wildcat Mountain a spider was found in a hollow stump. Michigan collecting labels of Dr. A. M. Chickering indicate localities in Ott Biological Preserve, in Calhoun County, Douglas Lake in Cheboygan County and dry hardwood and oak-hickory in Barry County. 

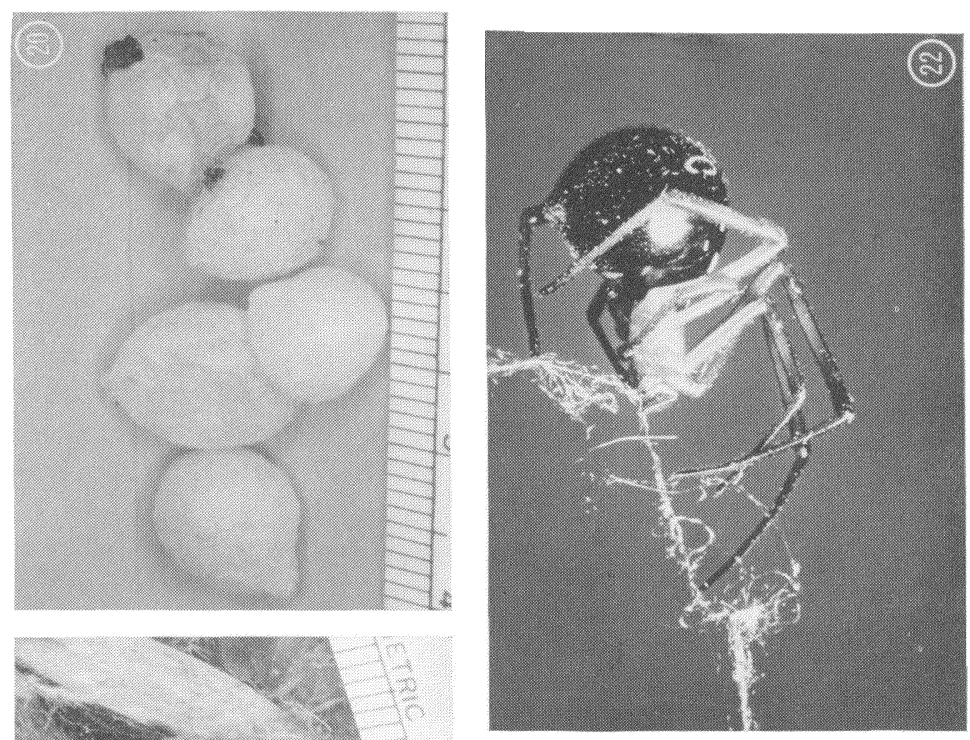

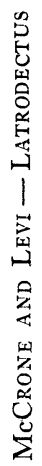
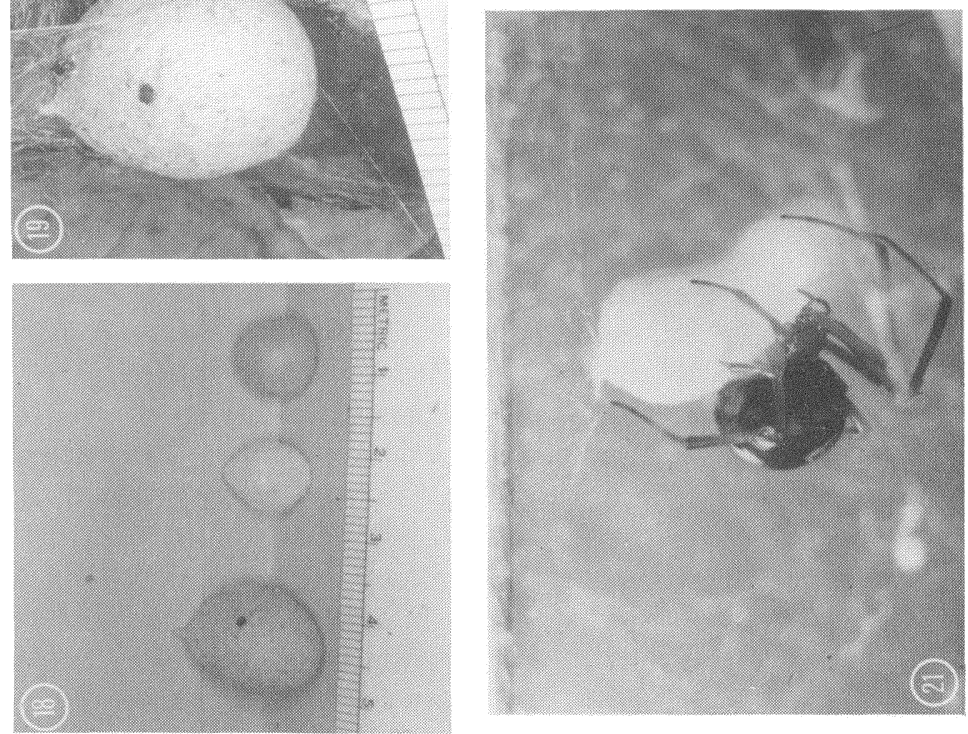
Latrodectus mactans is sympatric with both $L$. bishopi and L. variolus in Florida. It has been found in the same sand-pine scrubs as $L$. bishopi and in Torreya State Park with L. variolus. In both places it makes its webs near the ground. It seems to prefer ground depressions around the bases of palmetto bushes in the sand-pine scrub, and debris and rocks in Torreya State Park. It readily invades disturbed areas.

The most striking difference between $L$. mactans and $L$. variolus is the difference in their rate of post-embryonic development. Both species spend almost exactly the same amount of time in the egg sac but after emergence there is a marked difference in the length of time and the number of molts to maturity.

Twelve $L$. mactans egg sacs and Io $L$. variolus egg sacs were formed in the laboratory in St. Petersburg during the summer of 1963. The average length of time spent in the egg sac by $L$. mactans spiderlings was $29.3 \pm \mathrm{I} .3$ days (range 27-3I) and the average length of time for L. variolus spiderlings was 29.3 $\pm \mathrm{I} .3$ days (range 28-3I ).

Fifty of the spiderlings that emerged from an egg sac of L. mactans on I6 June I963, and fifty that emerged from an egg sac of $L$. variolus on 19 June 1963 , were taken for observation and rearing. Both egg sacs had been produced in the laboratory by individuals collected in northwest Florida. Each of the IOO spiderlings was placed in an individual, numbered container and these containers were then placed in an air-conditioned room where the temperature was kept reasonably constant around $24^{\circ} \mathrm{C}$. The spiderlings received a plentiful supply of living fruit flies, Drosophila melanogaster. When the immature spiders were large enough, they were fed as many housefly maggots as they would take, until they reached maturity. Originally we had planned to feed them adult flies, but both species showed a decided preference for the maggots. At no time were the developing spiders given water; all fluid came from the food. It was our experience that the addition of water is unnecessary and may encourage mold, which inhibits growth or may be lethal. A record was kept for each developing spider of the number of molts and the duration of the stadia

Explanation of Plate 3

Fig. 18. Egg sacs (from left to right), Latrodectus variolus, L. bishopi and L. mactans, all Florida.

Fig. 19. Egg sac of L. variolus.

Fig. 20. Successive egg sacs of an individual female of Latrodectus mactans tredecimguttatus from Israel (in Florida laboratory culture; order unknown). Figs. 21-22. Latrodectus bishopi Kaston, females. (Photograph by H. K. Wallace) 

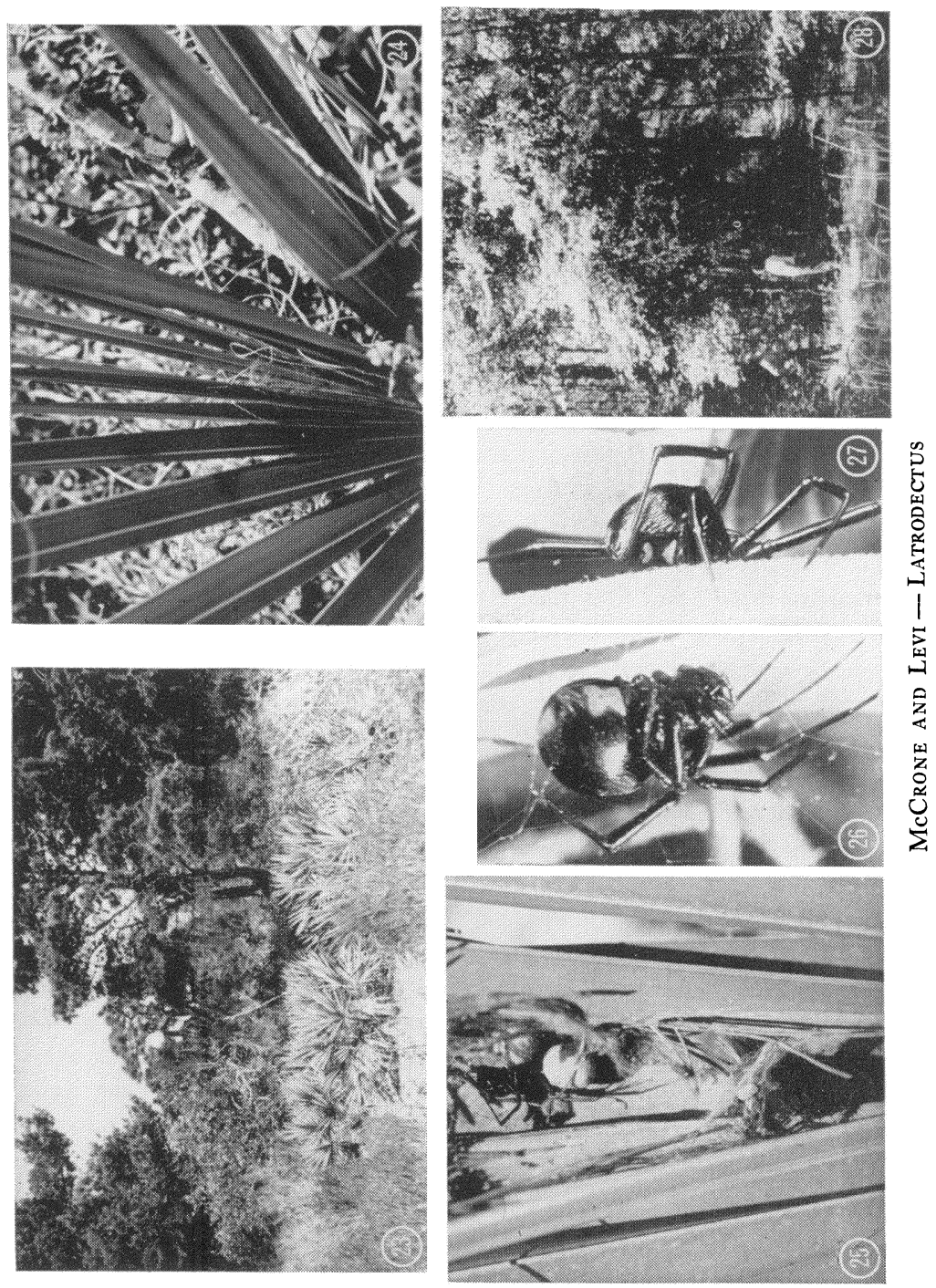
passed through to maturity. The first post-emergence molt was considered the first molt. These data are summarized in Table I.

A total of 45 L. mactans and $44 L$. variolus reached maturity. The sex ratio for $L$. mactans was 19 males to 26 females, for $L$. variolus 22 males to 22 females. A chi-square analysis at the $5 \%$ level of significance demonstrated that both these ratios are consistent with the hypothesis of a $\mathbf{I}: \mathrm{I}$ sex ratio.

Male $L$. mactans passed through fewer molts to maturity (mode 4) than male L. variolus (mode 7). Male L. mactans matured in an average of $42.0 \pm 7.8$ days (range $32-58$ ) while male $L$. variolus took much longer, I $29.6 \pm 7.5$ days (range I22-1 35 ).

The same relationship held for the females. Latrodectus mactans females required from 5 to 8 molts (mode 6) to maturity, L. variolus females 7 or 8 molts (mode 7 ). Females of L. mactans averaged 63.8 \pm 9.4 days (range 53-90) to maturity, while females of $L$. variolus averaged $152.6 \pm 17.9$ days (range 125-199). The discrepancy in number of instars suggests that the greater number of molts of $L$. variolus determines the very much larger size of the males, and also that the size variation and well-known variation in coloration of $L$. mactans males might be due to the different number of molts undergone.

\section{Species Relationships}

Latrodectus bishopi and L. variolus are certainly distinct species, but the close similarity between the two in morphology and their allopatric distribution suggests that $L$. bishopi might have been derived from $L$. variolus. It is known that the sand-pine scrubs inhabited by $L$. bishopi arose in connection with islands that were present in the Florida area during the Pleistocene (Laessle, I958). The literature (see Neill, I957) records a number of species that are endemic to these scrubs or other south-central habitats in Florida. Many of these species are closely related to other species whose ranges extend only into northern Florida. Thus the conjecture can be made that $L$. bishopi differentiated from $L$. variolus on an isolated island or island group in the Pleistocene seas.

\section{Explanation of Plate 4}

Figs. 23-25. Habitat of L. bishopi. 23. Florida scrub pine. 24. Web in palmetto. 25. Close-up of female with egg sac in palmetto.

Fig. 26. Latrodectus mactans (Fabricius) female from Tennessee.

Fig. 27. Latrodectus variolus Walckenaer, female from northern Florida. (Photograph by H. K. Wallace)

Fig. 28. Habitat of L. variolus in lower limbs of trees in northwestern Flo:ida. 


\section{VENOMS}

The results of a toxicological study of differences between the venoms of $L$. mactans, $L$. variolus and $L$. bishopi, and those of $L$. mactans tredecimguttatus from Israel and L. geometricus, will be published elsewhere (McCrone).

\section{Literature Cited}

Abalos, J. W.

1962. The egg sac in the identification of species of Latrodectus (Black Widow Spiders). Psyche, 69:268-270.

Abalos, J. W. ANd E. C. BaEz

1963. On spermatic transmission in spiders. Psyche, $70: 197-207$.

GERHARDT, U.

1933. Neue Untersuchungen zur Sexualbiologie der Spinnen, inbesondere an Arten der Mittelmeerländer und der Tropen. Zeitschr. Morph. Ok. Tiere, 27:1-75.

Hasselt, A. W. M. von

1860. Studien over de Z. G. Curacaosche Oranje Spin. Tijdschr. Ent., $3: 46-65$.

1887. Araneae Exoticae Insulis Caraçao, Bonaire et Aruba. Ibid. $30: 277-244$.

Kaston, B. J.

1938. Notes on a new variety of black widow spider from southern Florida. Florida Entom., $21: 60-61$.

1948. Spiders of Connecticut. Bull. Connecticut Geol. Nat. Hist. Surv., No. $70: 1-874$.

Laessle, Albert M.

1958. The origin and successional relationship of sandhill vegetation and sand-pine scrub. Ecol. Monographs, 28:361-387.

LeVI, Herbert W.

1959. The spider genus Latrodectus (Araneae, Theridiidae). Trans. Amer. Micros. Soc., 78:7-43.

Müller, P. L. S.

1776. Des Ritters Carl von Linné .. Wollständiges Natursystem, Nürnberg.

NEILL, WILFRED T.

1957. Historical biogeography of present-day Florida. Florida State

Nicolet, H. Museum Bull., $2: 175-220$.

1849. Arácnidos in Gay, C. Historia física y política de Chile, 3 :319543.

Shulov, A.

1940. On the biology of two Latrodectus spiders in Palestine. Proc.

WALCKENAER, C. A.

Linn. Soc. London, 152:309-328.

1837. Histoire Naturelle des Insectes Aptères, Paris, vol. 1. 

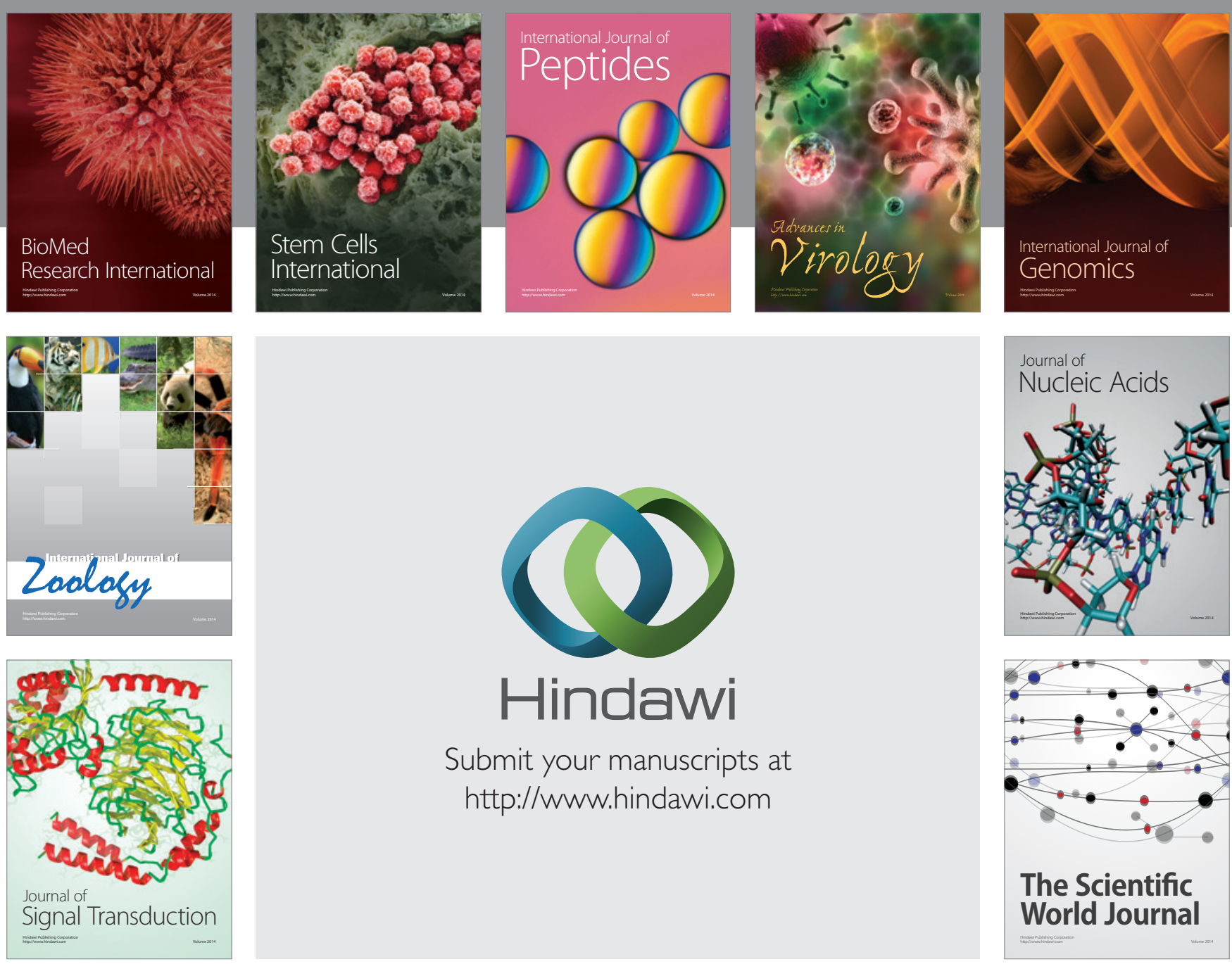

Submit your manuscripts at

http://www.hindawi.com
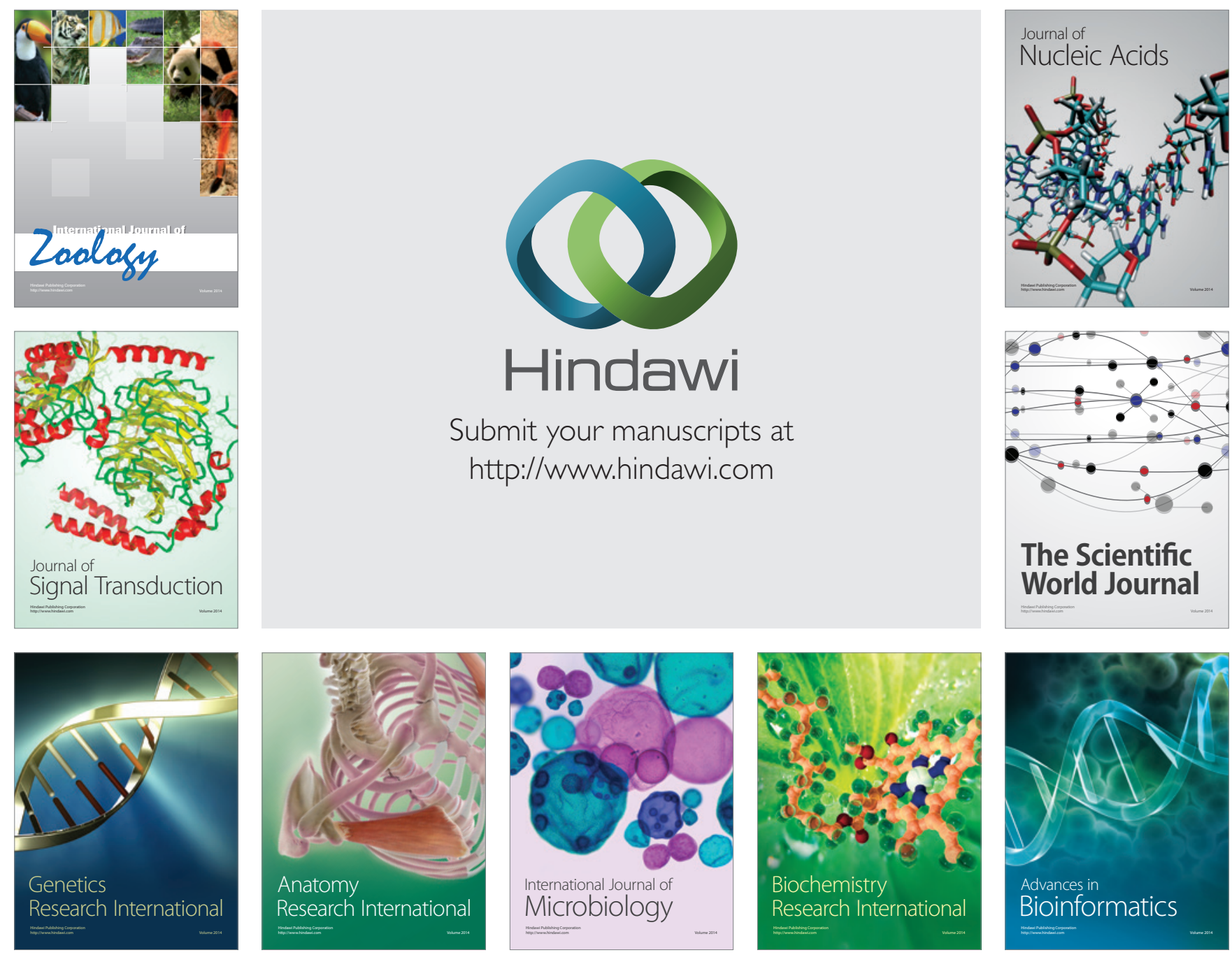

The Scientific World Journal
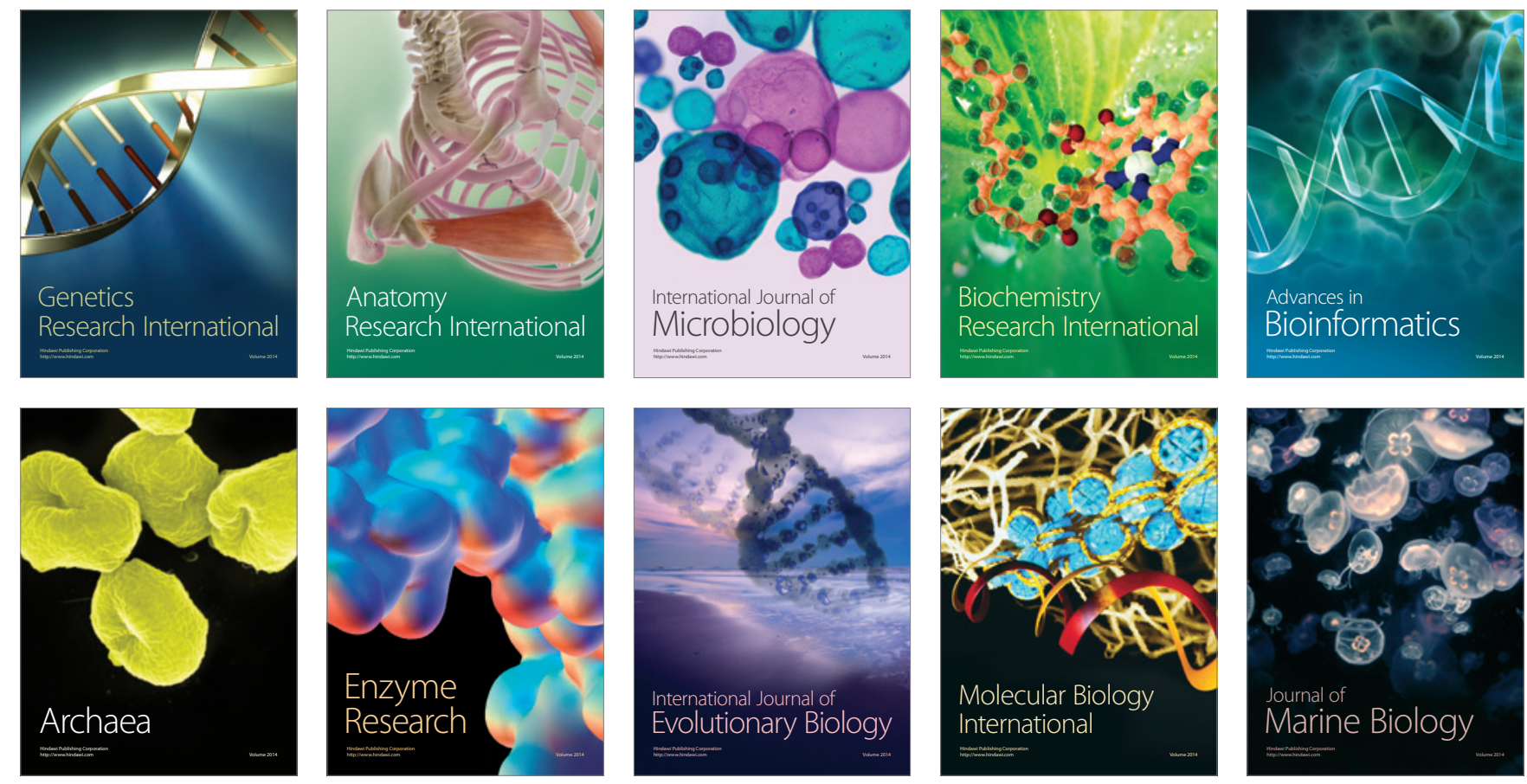